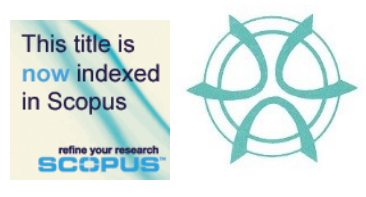

\title{
SPATIAL PATTERN OF RESIDENTIAL BURGLARY. THE CASE STUDY: KUCHING, SARAWAK
}

\author{
Norita Jubit $^{1}$, Tarmiji Masron ${ }^{2}$, Azizan Marzuki ${ }^{3}$ \\ ${ }^{1,2}$ Centre for Spatially Integrated Digital Humanities (CSIDH), \\ Faculty of Social Science and Humanities \\ UNIVERSITI MALAYSIA SARAWAK \\ ${ }^{3}$ School of Housing, Building \& Planning, \\ UNIVERSITI SAINS MALAYSIA
}

\begin{abstract}
Residents in Malaysia are mostly concentrated in urban areas. However, people do feel worried about residential burglary despite living in urban areas. Although burglary cases have recorded a decline, the fears of crime are still high among the people in Kuching, Sarawak. The objective of this study is to identify the spatial pattern of residential burglary in Kuching, Sarawak. This study is using Global Moran's I method as it can evaluate the spatial autocorrelation of residential burglary in the global context. The spatial data consists of Kuching district boundary, road data, police station boundary and police sector boundary, while non-spatial data includes residential burglary from 2015-2017, time, addresses of the crime occurrences, latitude and longitude. The result revealed that the strong global spatial patterns were found for residential burglary in Kuching, Sarawak between 2015 and 2017. However, there was no global spatial pattern found for residential burglary in 2016 .
\end{abstract}

Keywords: Spatial Pattern, Urban Property, Global Moran's I, Kuching

\footnotetext{
${ }^{1}$ Postgraduate (PhD) at Universiti Malaysia Sarawak. Email: noritajubit90@gmail.com
} 